boats to the 'mother' fishing ship. As a boat sets out fishing, it carries one of these sets. When the work is done, if there is a dense fog, the dory sends out a code signal to the mother ship. By means of the radio direction finder the ship carries, the direction of the dory from it is easily found. Tests made from a schooner show that dories can be located up to a distance of six miles. The battery used can give out signals for a week. A description of the method is given in Electronics of August.

\section{Japanese Mathematical Journals}

IT is interesting to notice how largely the English language is used in some Japanese scientific journals. The Tohoku Mathematical Journal accepts contributions in English, French, German, Italian or Japanese, but of the thirty-three papers in vol. 39, part 2 , no less than twenty-four are in English, and only one is in Japanese. The authors are of decidedly varied nationalities, including ten Americans, nine Japanese, four British, three Chinese, two Germans, and one Russian. The subjects treated belong almost entirely to the domain of pure mathematics, with an unusually large proportion of geometry of various kinds (pure, algebraic and differential). The papers in this Journal are usually very short. We have also received Science Reports of the Tokyo Bunrika Daigaku (Section A, 2, Nos. 31-32), which contain two mathematical papers of greater length, one in English and one in German, both by Japanese authors.

\section{The Trees of Ireland}

THE mild, moist climate of Ireland is particularly favourable to the growth of trees, and Mr. H. M. Fitzpatrick has done a valuable service to both foresters and botanists in gathering together (Sci. Proc. Roy. Dublin Soc., 41, November 1933) particulars of the trees introduced into Ireland, and as to where specimens of these trees may be found. Statistics of tree dimension have been collected from no less than seventy-two estates. The wide variety in conifers is particularly striking in the list. Mr. Fitzpatrick states that broad-leaved trees have been less and less in fashion since the introduction, about 1840, of many of the North American conifers, which flourish so remarkably in the Irish climate.

\section{Guide to Official Statistics}

ThE volume for 1933 of the "Guide to Current Official Statistics" (H.M. Stationery Office. 1s.) has now been published. The main part of the volume is an alphabetical subject index of nearly three hundred pages giving the number of the publication involved. This is followed by a list of publications in serial order which allows the title and price of the blue book or white paper to be found. The indexing is done in much detail, and there should be no difficulty in finding the statistics required. With the help of this annual publication, much valuable information in official volumes is made available to students.

\section{Announcements}

LORD MELCHeTT will speak on "National Progress in relation to the Monetary System" at a meeting of the Engineers' Study Group on Economics on October 24 at 8 p.m. at Denison House, Victoria, S.W.1. Admission is by tickets, obtainable free of charge from Mr. A. H. Hayes, Hazlitt House, Chancery Lane, W.C.2.

The following appointments have been made in the Colonial Empire: Mr. L. D. E. F. Vesey-Fitzgerald, to be entomologist to the Sugar-Cane Investigation Committee, Trinidad; Mr. R. A. Hamilton, to be assistant chemist to the Sugar-Cane Investigation Committee, Trinidad; Mr. G. D. Huggins, assistant agricultural superintendent, British Guiana, to be agricultural superintendent, British Guiana; Mr. J. V. Collins, deputy Government analyst, Ceylon, to be Government Analyst, Ceylon; Mr. G. W. St. C. Thompson, formerly botanist, Tsetse Research Department, Tanganyika Territory, to be Assistant Conservator of Forests, Gold Coast.

IT is announced from the Royal Institution that single tickets admitting to one afternoon lecture can now be obtained by non-members. Books of single tickets, which are transferable, are also available, and season tickets for the sessions before and after Christmas respectively can be obtained.

The Institute of Chemistry, the Society of Chemical Industry and the Institute of Metals will shortly be making awards from the Beilby Memorial Fund. These awards are given to British investigators in science to mark appreciation of records of distinguished original work, preference being given to investigations relating to the special interests of Sir George Beilby, including problems connected with fuel economy, chemical engineering and metallurgy. The administrators of the Fund will be glad to have their attention directed, not later than October 27, to outstanding work of the nature indicated. Correspondence should be addressed to the Convener, Sir George Beilby Memorial Fund, Institute of Chemistry, 30 Russell Square, London, W.C.1.

Applications are invited for the following appointments, on or before the dates mentioned :-A senior lecturer in physics at the Military College of Science, Red Barracks, Woolwich, S.E.18-The Commandant (Oct. 31). A professor of economies at Armstrong College, Newcastle-upon-'Tyne-The Registrar (Nov. 12). A temporary assistant metallurgist at the Research Department, Woolwich, S.E.18-The Chief Superintendent. An irrigation adviser to the Palestine Government-The Crown Agents for the Colonies, 4 Millbank, London, S.W.1. A lecturer in physics at the University of Rangoon (University College) The Secretary, Universities Bureau of the British Empire, 88A, Gower Street, London, W.C.1. An assistant in the Mechanical Engineering Department of Guildford Technical College-The Director, Technical College, Park Street, Guildford. An assistant in radio research in the Directorate of Scientific Research of the Air Ministry-The Chief Superintendent, Royal Aircraft Establishment, South Farnborough, Hampshire. 